\title{
Hepatic Abscesses in the Immunocompromised Patient: Role of CT in Detection, Diagnosis, Management, and Follow-Up
}

\author{
Isaac R. Francis, Gary M. Glazer, Marco A. Amendola, and Stephen W. Trenkner \\ Department of Radiology, University of Michigan Medical Center, Ann Arbor, Michigan, USA
}

\begin{abstract}
Newer cytotoxic and immunosuppressive agents and more aggressive oncologic treatment protocols have resulted in an increased incidence of opportunistic infections in the immunocompromised host. Clinical symptoms and laboratory data are often nonspecific and definitive diagnosis may be difficult to establish. The role of CT in the detection, diagnosis, management, and followup of various hepatic opportunistic infections in 9 immunocompromised hosts is presented.

In 5 of 6 patients, CT-guided needle aspiration resulted in definitive diagnosis. In 3 patients, surgical intervention was obviated by abscess drainage using CT guidance. There is clearly a role for CT not only in the detection but also in the definitive diagnosis, treatment, and follow-up of abscesses in the immunocompromised host.
\end{abstract}

Key words: Liver, abscess - Liver, computed tomography.

A new spectrum of opportunistic infections has been introduced into current clinical practice with the increasing use of steroids, cytotoxic drugs, other immunosuppressive agents, and antibiotics, particularly in the immunocompromised host [1, 2]. In many instances, the clinical symptoms in these patients are nonspecific, resulting in a delay in diagnosis and increased morbidity and mortality. We present here our experience utilizing computed tomography (CT) in the detection, definitive diagnosis, treatment, and follow-up of hepatic abscesses in the immunocompromised host.

Address reprint requests to: Isaac R. Francis, M.D., Department of Radiology-Box 13, University of Michigan Medical Center, Ann Arbor, MI 48109, USA

\section{Materials and Methods}

The medical records and CT findings in 9 immunocompromised hosts with proven hepatic abscesses were analyzed retrospectively. Four patients were male and 5 were female; they ranged in age from 15 to 65 years. Underlying disease processes included acute myelogenous leukemia in 3 patients, chronic granulomatous disease in 3 children, and diabetes mellitus in 3 other patients.

All patients were scanned using either a GE 8800 or 9800 $\mathrm{CT} / \mathrm{T}$ scanner, using contiguous $10-\mathrm{mm}$ sections. Scans were obtained after administration of oral and intravenous contrast material (bolus injection of 75-100 cc meglumine iothalamate $60 \%$, followed by rapid drip infusion of meglumine iothalamate $30 \%$ ).

The diagnosis was established by percutaneous needle aspiration in 6 patients ( 5 with CT-guided biopsies and 1 with unguided liver biopsy), surgical biopsy in 2 patients, and autopsy in 1 patient. In 3 patients, surgical intervention was obviated by abscess drainage under CT guidance.

\section{Results}

The symptoms, clinical and laboratory data, and CT findings are listed in Table 1. In most instances, the clinical presentation and liver function abnormalities were nonspecific. The interval between the onset of symptoms and the establishment of a definitive diagnosis varied from 1 to 12 weeks and averaged 6 weeks.

Disseminated fungal microabscesses were demonstrated in 3 patients with acute myelogenous leukemia. These microabscesses were seen on CT as multiple rounded areas of diminished attenuation scattered throughout the splenic and liver parenchyma, ranging in size from 2 to $20 \mathrm{~mm}$ (Fig. 1). In 1 patient, "target lesions" were seen: a small, higher-attenuation nidus (probably mycelial) centrally located within the low-attenuation, necrotic, zone. Disseminated candidal infection was the causative agent in 2 patients, while 1 patient had disseminated aspergillosis. One of the patients with 
Table 1. Clinical findings in 9 patients

\begin{tabular}{|c|c|c|c|c|c|c|c|c|}
\hline $\begin{array}{l}\mathrm{Pa}- \\
\text { tient }\end{array}$ & $\begin{array}{l}\text { Age } \\
\text { (yrs) }\end{array}$ & Sex & $\begin{array}{l}\text { Underlying } \\
\text { disease process }\end{array}$ & Symptoms & $\begin{array}{l}\text { Liver } \\
\text { function tests }\end{array}$ & $\begin{array}{l}\text { CT } \\
\text { findings }\end{array}$ & Proof & Final diagnosis \\
\hline 1 & 26 & $\mathrm{~F}$ & $\begin{array}{l}\text { Acute pro- } \\
\text { granulocytic } \\
\text { leukemia }\end{array}$ & $\begin{array}{l}\text { Fever, right } \\
\text { upper quadrant } \\
\text { pain }\end{array}$ & $\begin{array}{l}\text { SGOT } 2 \\
\text { SGPT } 4 \\
\text { LDH } 122 \\
\text { Alk. phos. } 59\end{array}$ & $\begin{array}{l}\text { Multiple } \\
\text { low-attenuation } \\
\text { areas in liver } \\
\text { and spleen, } \\
2-8 \mathrm{~mm}\end{array}$ & $\begin{array}{l}\text { CT-guided } \\
\text { aspirate }\end{array}$ & Candidiasis \\
\hline 2 & 53 & $\mathrm{~F}$ & $\begin{array}{l}\text { Acute myelo- } \\
\text { monocytic } \\
\text { leukemia }\end{array}$ & Fever & $\begin{array}{l}\text { SGOT } 14 \\
\text { SGPT } 36 \\
\text { LDH } 578 \\
\text { Alk. phos. } 309\end{array}$ & $\begin{array}{l}\text { Multiple } \\
\text { low-attenuation } \\
\text { areas in spleen } \\
\text { and liver, } \\
10-20 \mathrm{~mm}\end{array}$ & Autopsy & $\begin{array}{l}\text { Disseminated } \\
\text { aspergillosis }\end{array}$ \\
\hline 3 & 29 & $\mathrm{~F}$ & $\begin{array}{l}\text { Acute } \\
\text { myelogenous } \\
\text { leukemia }\end{array}$ & $\begin{array}{l}\text { Persistent } \\
\text { fever }\end{array}$ & $\begin{array}{l}\text { SGOT } 26 \\
\text { SGPT } 45 \\
\text { LDH } 150 \\
\text { Alk. phos. } 348\end{array}$ & $\begin{array}{l}\text { Multiple } \\
\text { low-attenuation } \\
\text { areas in spleen } \\
\text { and liver, } \\
2-10 \mathrm{~mm}\end{array}$ & $\begin{array}{l}\text { Surgical } \\
\text { biopsy }\end{array}$ & Candidiasis \\
\hline 4 & 71 & $\mathrm{~F}$ & $\begin{array}{l}\text { Diabetes } \\
\text { mellitus }\end{array}$ & $\begin{array}{l}\text { Disorientation } \\
\text { and fever }\end{array}$ & $\begin{array}{l}\text { SGOT } 120 \\
\text { SGPT } 175 \\
\text { LDH } 281 \\
\text { Alk. phos. } 469\end{array}$ & $\begin{array}{l}\text { Large abscess } \\
\text { without air, } \\
8 \times 6 \times 6 \mathrm{~cm}\end{array}$ & $\begin{array}{l}\text { CT-guided } \\
\text { aspirate and } \\
\text { drainage }\end{array}$ & $\begin{array}{l}\text { Mixed organisms } \\
\text { including } E \text {. coli } \\
\text { and } S \text {. aureus }\end{array}$ \\
\hline 5 & 38 & $\mathrm{~F}$ & $\begin{array}{l}\text { Diabetes } \\
\text { mellitus }\end{array}$ & $\begin{array}{l}\text { Right upper } \\
\text { quadrant pain, } \\
\text { fever, nausea }\end{array}$ & $\begin{array}{l}\text { SGOT } 11 \\
\text { SGPT } 9 \\
\text { LDH } 153 \\
\text { Alk. phos. } 520\end{array}$ & $\begin{array}{l}\text { Air-containing } \\
\text { abscess right } \\
\text { lobe, } 7 \mathrm{~cm}\end{array}$ & $\begin{array}{l}\text { CT aspiration } \\
\text { and drainage }\end{array}$ & $\begin{array}{l}E . \text { coli, and } \\
\text { clostridium } \\
\text { species }\end{array}$ \\
\hline 6 & 22 & $\mathrm{~F}$ & $\begin{array}{l}\text { Chronic } \\
\text { granulomatous } \\
\text { disease }\end{array}$ & $\begin{array}{l}\text { Fevers, right } \\
\text { upper quadrant } \\
\text { pain }\end{array}$ & $\begin{array}{l}\text { SGOT } 16 \\
\text { SGPT } 8 \\
\text { LDH } 305 \\
\text { Alk. phos. } 334\end{array}$ & $\begin{array}{l}\text { Multiple } \\
\text { low-attenuation } \\
\text { areas, } 2-8 \mathrm{~cm} \text {, } \\
\text { larger } 1 \\
\text { containing gas } \\
\text { in addition to } \\
\text { multiple } \\
\text { calcifications }\end{array}$ & Surgical & $\begin{array}{l}\text { S. aureus and } \\
\text { mixed flora }\end{array}$ \\
\hline 7 & 17 & $\mathrm{M}$ & $\begin{array}{l}\text { Chronic } \\
\text { granulomatous } \\
\text { disease }\end{array}$ & $\begin{array}{l}\text { Pain upper } \\
\text { abdomen }\end{array}$ & $\begin{array}{l}\text { SGOT } 12 \\
\text { SGPT } 11 \\
\text { LDH } 124 \\
\text { Alk. phos. } 166\end{array}$ & $\begin{array}{l}\text { Low-attenuation } \\
\text { area in lateral } \\
\text { segment of left } \\
\text { lobe of liver, } \\
3 \mathrm{~cm}\end{array}$ & $\begin{array}{l}\text { CT-guided } \\
\text { aspirate }\end{array}$ & S. aureus \\
\hline 8 & 17 & M & $\begin{array}{l}\text { Chronic } \\
\text { granulomatous } \\
\text { disease }\end{array}$ & $\begin{array}{l}\text { Pain and } \\
\text { fever }\end{array}$ & $\begin{array}{l}\text { SGOT } 10 \\
\text { SGPT } \\
\text { LDH } \\
\text { Alk. phos. }\end{array}$ & $\begin{array}{l}\text { Multiple calci- } \\
\text { fications and } \\
\text { low-attenuation } \\
\text { areas, } 2-5 \mathrm{~cm}\end{array}$ & $\begin{array}{l}\text { CT-guided } \\
\text { aspirate }\end{array}$ & S. aureus \\
\hline 9 & 45 & $\mathbf{M}$ & $\begin{array}{l}\text { Diabetes and } \\
\text { prior } \\
\text { splenectomy }\end{array}$ & $\begin{array}{l}\text { Right upper } \\
\text { pain and fever }\end{array}$ & $\begin{array}{l}\text { SGOT 1 } \\
\text { SGPT } 3 \\
\text { LDH } 149 \\
\text { Alk. phos. } 347\end{array}$ & $\begin{array}{l}\text { Multiple masses } \\
\text { in all lobes, } \\
10-20 \mathrm{~mm}\end{array}$ & $\begin{array}{l}\text { Unguided } \\
\text { liver aspirate }\end{array}$ & Actinomycosis \\
\hline
\end{tabular}

Normal levels: SGOT, 2-35 IU/L; SGPT, 2-35 IU/L; LDH, 60-200 IU/L; Alk. phos., 30-97 IU/L.

candidiasis proven by open liver biopsy had undergone previous CT-directed and undirected liver biopsies; these specimens were not diagnostic. In another patient, the diagnosis of disseminated candidal infection was established by CT-directed liver biopsy following examination of multiple undirected liver biopsy specimens, which were negative. Disseminated aspergillosis was confirmed at autopsy in the third patient (Fig. 2).
Three patients with chronic granulomatous disease of childhood had liver abscesses diagnosed using CT; 2 of these patients have been documented in a previous report [3]. Hepatic calcifications were demonstrated in all 3 patients, and multiple hepatic abscesses were seen in 2 (Fig. 3). In the third patient, a solitary hepatic abscess was successfully drained percutaneously using CT guidance. Cultures from the abscesses in all 3 patients 

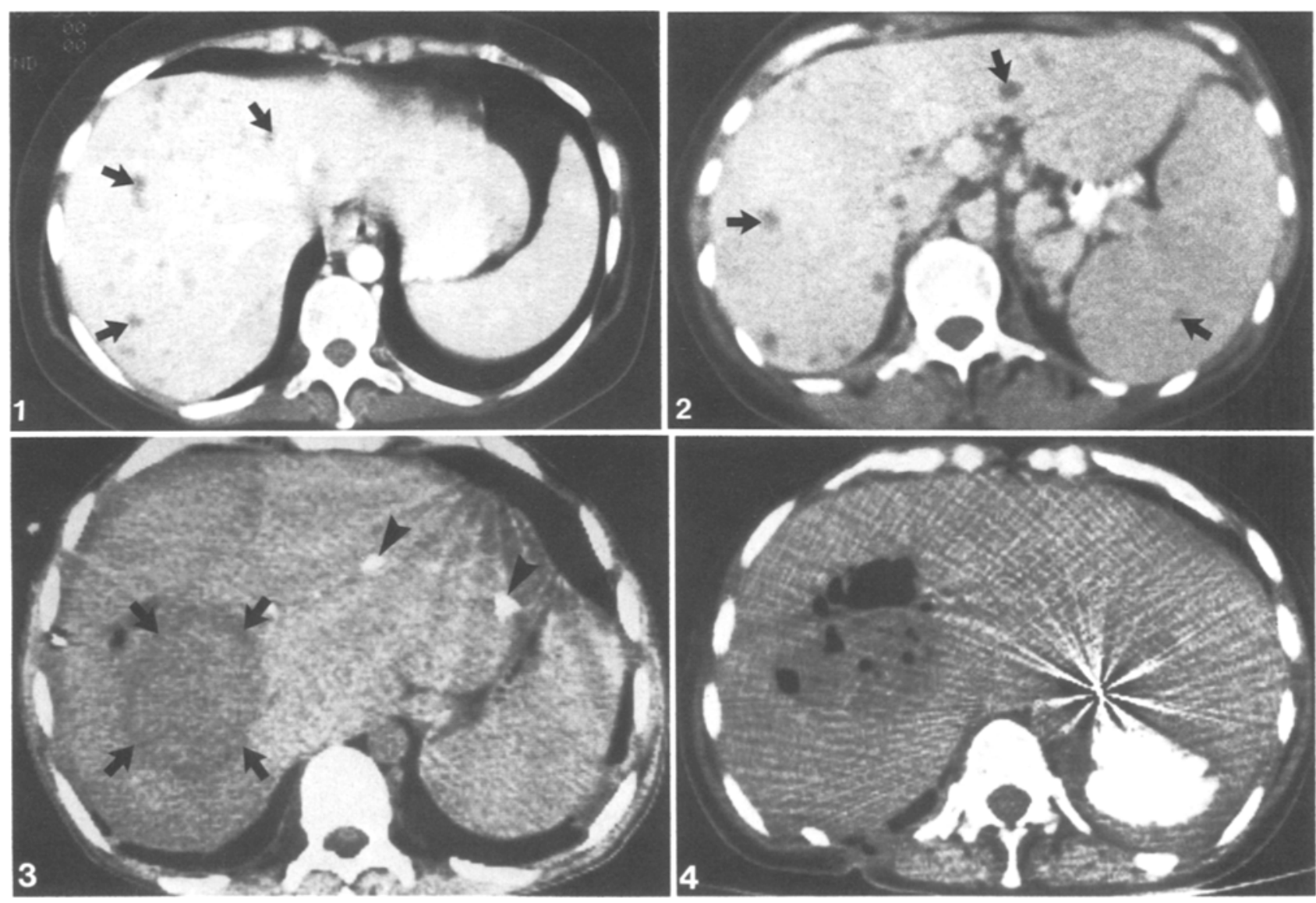

Fig. 1. Contrast-enhanced scan demonstrates numerous low-attenuation areas (arrows) throughout the liver parenchyma in a patient with acute myelogenous leukemia. Open liver biopsy following nondiagnostic CT-guided biopsy revealed hepatic candidiasis.

Fig. 2. Low-attenuation lesions seen in liver and spleen (arrows) in a patient with acute myelogenous leukemia. At autopsy, disseminated aspergillosis was proven.

Fig. 3. Hepatomegaly, calcifications (arrowheads), and large, hepatic abscess (arrows) in a child with chronic granulomatous disease. Multiple abscesses were also present on other scans. Surgical drainage was performed, and cultures from these abscesses grew mixed flora including Staphylococcus aureus.

Fig. 4. Clostridial liver abscess with gas bubbles in a diabetic patient was initially drained percutaneously using $\mathrm{CT}$ guidance. Surgical intervention was necessary later for recurrent hepatic abscess and associated empyema.

grew multiple organisms including Staphylococcus aureus.

Three patients with hepatic abscesses and underlying diabetes mellitus were included in the study. In 2, solitary hepatic abscesses, including a large gas-containing clostridial abscess (Figs. 4 and 5), were drained under CT guidance. Another diabetic patient, who previously underwent distal pancreatectomy with splenectomy for chronic pancreatitis, had persistent abdominal pain and nonspecific abnormalities of liver enzymes. Multiple echogenic masses were demonstrated on the sonogram, which, however, did not have the characteristic features of cavernous hemangiomas on CT (Fig. 6). Unguided liver biopsy performed to exclude metastatic disease yielded the diagnosis of hepatic actinomycosis.

\section{Discussion}

The advent of newer cytotoxic drugs, immunosuppressive agents, and increased use of antibiotics, particularly in the immunocompromised host, has led to an increase in the incidence of opportunistic infections. These infections are usually due to organisms indigenous to the host or found frequently in the environment which do not produce significant disease in normal individuals. Infections in the immunocompromised host are often occult, and the delay in diagnosis contributes to increased mortality. These opportunistic infections are the result of a variety of underlying factors (Table 2), which include defects in anatomical areas such as the skin and mucous membranes and a host of inherited and acquired disorders of the host de- 

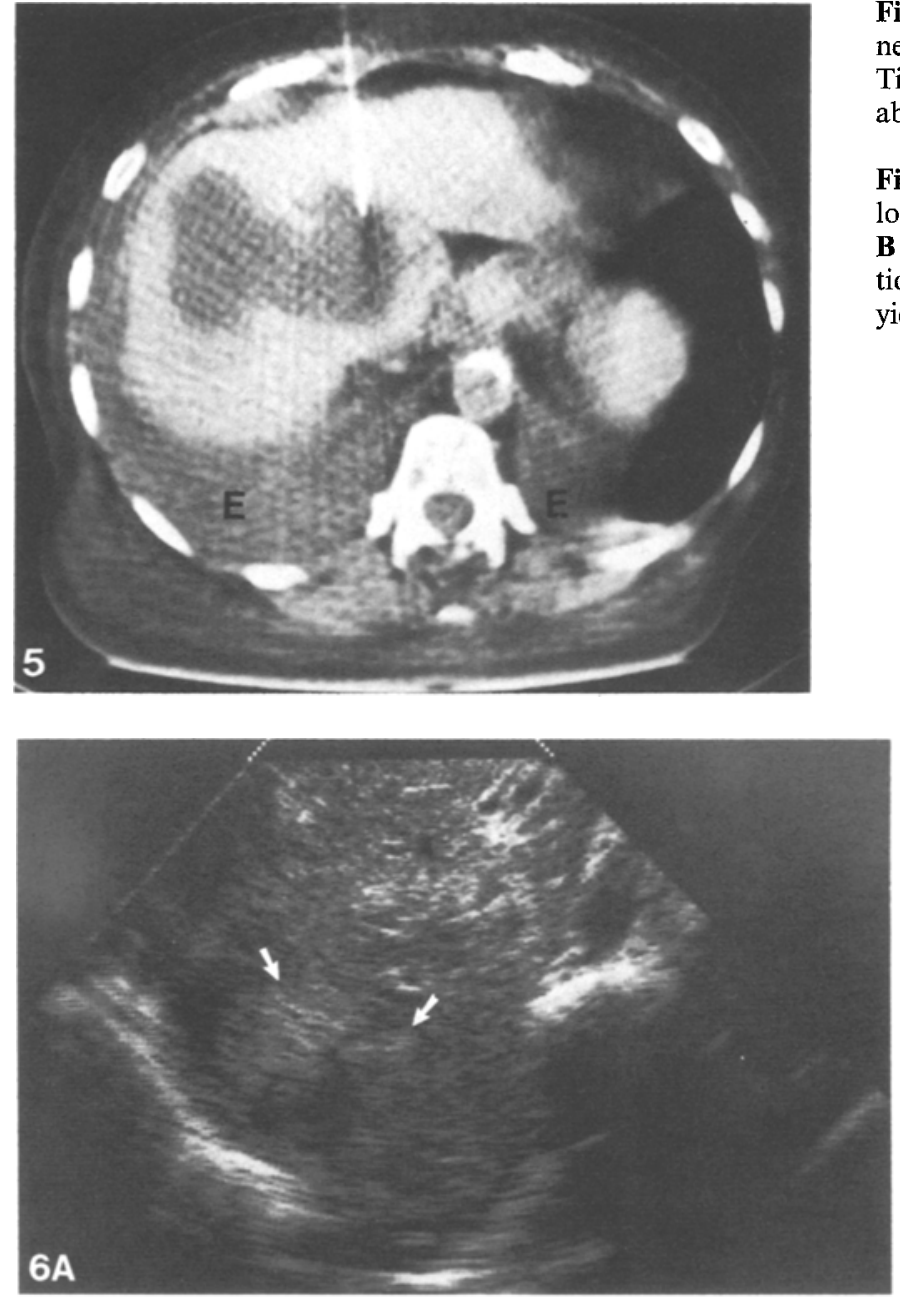

Fig. 5. Multilocular abscess in a diabetic patient. Percutaneous needle aspiration and definitive drainage under CT guidance. Tip of 18-gauge needle is seen within the medial aspect of the abscess. E, sympathetic pleural effusions.

Fig. 6. A Transverse real-time sonogram through right hepatic lobe demonstrates multiple echogenic lesions (white arrows). B Contrast-enhanced CT demonstrates multiple low-attenuation areas (black arrows). Unguided needle aspiration biopsy yielded the diagnosis of hepatic actinomycosis.

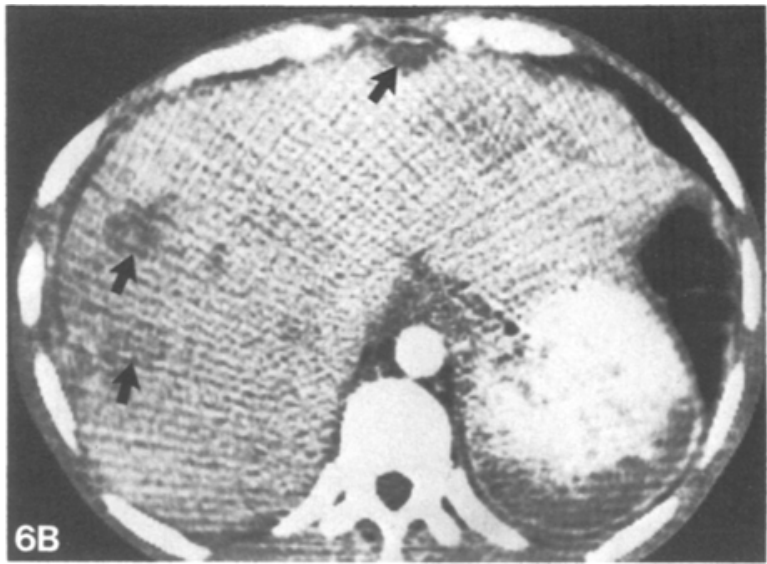

fense system. The major predisposing causes in the latter group include immunosuppression, underlying malignancy, organ transplantation, diabetes mellitus, uremia, collagen diseases, and, in children, chronic granulomatous disease.

In the last 2 decades, an increasing incidence of disseminated fungal infections has been reported in compromised hosts by various authors $[4,5]$. The increasing incidence of disseminated candidiasis largely reflects the recent, more aggressive approach to the treatment of leukemia. Remission is induced by establishing marrow aplasia, followed by repopulation of the marrow with normal nonneoplastic hematopoietic tissue, resulting in a period of prolonged granulocytopenia [5]. While the other effects of cytotoxic drugs and antibiotics, such as a decrease in macrophage function and suppression of cellular and humoral immunity, play a role, prolonged granulocytopenia may be the major predisposing factor to opportunistic infections [5]. Although Candida is responsible for most disseminated fungal infections, other types of disseminated infection include aspergillosis, mucormycosis, cryptococcosis, and histoplasmosis [1, 4]. In patients with disseminated candidiasis, GI tract involvement is very common, especially in patients with leukemia; and there is a high frequency of hepatic and splenic involvement as well [5]. The role of CT in the detection, diagnosis, and follow-up of hepatic and splenic microabscesses from disseminated fungal infections has been reported previously [6-9]. As in our patients, these lesions usually appear as multiple, low-attenuation lesions of varying size in the liver and spleen. Rarely, one may see the central nidus of mycelia with surrounding necrosis resulting in the "target" lesions. These "target" lesions may be more commonly seen on ultrasonography than on CT and were seen in only 1 patient in our study. While this appearance in the immunocompromised host is highly suggestive of hepatic fungal microabscesses, it is by no means specific. Recently, a 
Table 2. Opportunistic infection in patients with inherited and acquired disorders

\begin{tabular}{|c|c|}
\hline Predisposing causes & Suggested mechanisms \\
\hline $\begin{array}{l}\text { Chronic granulomatous } \\
\text { disease }\end{array}$ & $\begin{array}{l}\text { Impaired production of } \mathrm{H}_{2} \mathrm{O}_{2} \\
\text { with defective bactericidal } \\
\text { function }\end{array}$ \\
\hline $\begin{array}{l}\text { Chediak-Higashi } \\
\text { syndrome }\end{array}$ & $\begin{array}{l}\text { Defective bactericidal activity, } \\
\text { impaired chemotaxis, neutropenia }\end{array}$ \\
\hline Splenic insufficiency & $\begin{array}{l}\text { Defective opsonization; defective } \\
\text { clearing of organisms }\end{array}$ \\
\hline $\begin{array}{l}\text { Humoral immuno- } \\
\text { deficiency syndrome } \\
\text { (predominantly B cell } \\
\text { defects) }\end{array}$ & $\begin{array}{l}\text { Reduced phagocytic efficiency; } \\
\text { failure of lysis and agglutina- } \\
\text { tion of bacteria; inadequate } \\
\text { neutralization of bacterial toxins }\end{array}$ \\
\hline $\begin{array}{l}\text { Cellular immuno- } \\
\text { deficiency syndromes } \\
\text { (predominantly } \mathrm{T} \text { cell } \\
\text { defects) }\end{array}$ & $\begin{array}{l}\text { Absence or impaired delayed } \\
\text { hypersensitivity response; absent } \\
\mathrm{T} \text { cell cooperation for } \mathrm{B} \text { cell } \\
\text { synthesis of antibodies to } \\
\text { T-cell-specific antigens }\end{array}$ \\
\hline Cancer & $\begin{array}{l}\text { Granulocytopenia; decreased } \\
\text { neutrophil chemotaxis; decreased } \\
\text { bactericidal activity of neutro- } \\
\text { phils; lymphopenia, defective } \\
\text { cell-mediated immunity; impaired } \\
\text { antigenic response to challenge }\end{array}$ \\
\hline Immunosuppression & Dependent upon agent used \\
\hline Diabetes mellitus & $\begin{array}{l}\text { Impaired phagocytic activity; } \\
\text { decreased serum opsonizing } \\
\text { capacity; decreased chemotaxis } \\
\text { of neutrophils }\end{array}$ \\
\hline Collagen diseases & $\begin{array}{l}\text { Probably related to use of } \\
\text { immunosuppressive agents; may } \\
\text { relate to involvement of reticulo- } \\
\text { endothelial system }\end{array}$ \\
\hline
\end{tabular}

similar appearance has been reported in patients with staphylococcal hepatic microabscesses [10]. The assessment of response to therapy is difficult in these patients due to their nonspecific clinical symptoms and results of laboratory tests. Therefore, serial scans may be essential for assessing response to therapy. In 2 of these 3 patients, CT was useful in this setting by demonstrating a decrease in number and size of hepatic and splenic lesions after institution of antifungal therapy.

Hepatic abscesses in infancy are uncommon and are usually secondary to omphalitis or umbilical vein catheterization [11-14]. Children with chronic granulomatous disease are at an increased risk for developing hepatic abscesses. A review of the literature suggests that $40 \%$ of hepatic abscesses in persons under the age of 20 occur in children with chronic granulomatous disease [11]. Other common sites of infection in patients with granulomatous disease include the skin, respiratory tract, lymph nodes, and bones. Recurrent infections in these children are secondary to an inability of polymorphonuclear leukocytes to destroy certain ingested bacteria and fungi. Defective hydrogen peroxide formation due to a variety of enzymatic abnormalities is the underlying defect $[15,16]$. The most common organism appears to be Staphylococcus aureus, as was the case in all 3 patients in this study. Two of these patients had multiple abscesses; the third had a solitary left lobe abscess.

Patients with diabetes mellitus have decreased resistance to bacterial and fungal infections. Possible causative factors include sluggish polymorphonuclear leukocyte response to infection, ineffective phagocytosis, lack of fibroblast production, and a decrease in the opsonizing capacity of serum $[17,18]$. Fungal infections, particularly by mucormycosis and candidiasis, have been reported with greater frequency in diabetic children than in the normal host, but this is probably related to the repeated use of antibiotics in the former [19]. Two of 3 patients with diabetes in our study had solitary hepatic abscesses including a large clostridial abscess, and the other diabetic patient, who had previously undergone splenectomy and distal pancreatectomy, developed hepatic actinomycosis.

Actinomycosis is an unusual infection in current clinical practice in the United States and is more common in the noncompromised host than in the compromised host. Common sites of involvement include the neck, face, thorax, and abdomen. Chronic inflammatory processes as well as surgical procedures or perforation of the GI tract are common predisposing factors. The organism commonly involves the liver, spleen, brain, and ovaries. Liver involvement is probably via portal vein seeding after penetration through the bowel wall $[20,21]$. Patients with a prior splenectomy have an increased risk of developing infectious processes, although usually their susceptibility is influenced by the underlying disease for which the splenectomy was performed [22, 23]. The increased susceptibility to actinomycosis in the patient in our study might have been related to a combination of previous splenectomy and underlying diabetes.

Ultrasonography and CT are not only of value in the detection of hepatic abscesses but can also be utilized to guide interventional procedures for definitive diagnosis and treatment [24 27]. This is necessary, since although the CT and ultrasound appearances of disseminated fungal infection are highly suggestive of the diagnosis, they are not entirely specific, and a definitive diagnosis (based on either histologic examination or culture) is required before therapy can be instituted because of the significant side effects of antifungal drugs. 
Also, pyogenic abscesses may not have a typical appearance and can be confused with a variety of benign and malignant hepatic lesions [28].

Seven patients underwent percutaneous needle aspiration biopsy ( 6 using CT guidance and 1 unguided biopsy), 2 surgical biopsy, and in 1 the diagnosis was established at autopsy. A definitive diagnosis was established in 5 of 6 patients $(83 \%)$ who underwent CT-guided aspiration. One false-negative result occurred in a patient with disseminated fungal sepsis, and that diagnosis was subsequently established by open surgical biopsy. Unguided liver biopsy was utilized to establish the diagnosis of hepatic actinomycosis. Open surgical aspiration and drainage was performed in 2 patients with chronic granulomatous disease and multiple hepatic abscesses.

Drainage guided by CT was performed in 3 of 10 patients; 2 patients had diabetes mellitus and the other had chronic granulomatous disease. This treatment was definitive in 2 of 3 patients; the patient with a large clostridial hepatic abscess required surgical drainage of the abscess and an associated empyema.

In conclusion, the increasing use of newer cytotoxic drugs, immunosuppressive agents, steroids, and antibiotics, along with aggressive radical surgical procedures and intensive irradiation, has resulted in an increase in the incidence of opportunistic infections. Computed tomography is capable of detecting and diagnosing sites of infection and guiding subsequent intervention including abscess drainage. We recommend the early use of CT in patients with suspected opportunistic infections to minimize the significant morbidity and mortality associated with untreated disease.

\section{References}

1. Hart PD, Russell E Jr, Remington JS: The compromised host and infection. II. Deep fungal infection. $J$ Infect Dis 120(2):169-191, 1969

2. Feigin RD: Opportunistic infections in the compromised host. In Feigin RD, Cherry JB (eds): Textbook of Pediatric Infectious Diseases. Philadelphia: W.B. Saunders, 1981, pp 769-786

3. Stricof DD, Glazer GM, Amendola MA: Chronic granulomatous disease: value of the newer imaging modalities. $\mathrm{Pe}$ diatr Radiol 14:328-331, 1984

4. Bodey GP: Fungal infections complicating acute leukemia. J Chron Dis 19:667-687, 1966

5. Myerowitz RL, Pazin GJ, Allen CM: Disseminated candidiasis. Changes in incidence, underlying diseases, and pathology. Am J Clin Pathol 68:29-38, 1977

6. Callen PW, Filly RA, Marcus FS: Ultrasonography and computed tomography in the evaluation of hepatic microabscesses in immunosuppressed patients. Radiology $136: 433-434,1980$
7. Ho B, Cooperberg PL, Lee LI, David KB, Mack L, Naiman SC, Grossman L: Ultrasonography and computed tomography of hepatic candidiasis in immunosuppressed patients. $J$ Ultrasound Med 1:157-159, 1982

8. Miller JH, Greenfield LD, Wald BR: Candidiasis of the liver and spleen in childhood. Radiology 142:375-380, 1982

9. Berlow ME, Spirt BA, Weil L: CT follow-up of hepatic and splenic fungal microabscesses. $J$ Comput Assist Tomogr $8(1): 42-45,1984$

10. Mathieu D, Vasile N, Fagniez P-L, Segui S, Grably D, Larde D: Dynamic CT features of hepatic abscesses. Radiology 154:749-752, 1985

11. Chusid MJ: Pyogenic hepatic abscess in infancy and childhood. Pedatrics 62(4):554-559, 1978

12. Kutsunai $\mathrm{T}$ : Abscess of the liver of umbilical origin in infants. Am J Dis Child 51:1385-1396, 1936

13. Kandall SR, Johnson AB, Gartner LM: Solitary neonatal hepatic abscess. J Pediatr 85:567-569, 1974

14. Barns YW, Ceballos R, Cassady G: Umbilical catheters in hepatic abscesses. Pediatrics 53:254-266, 1974

15. Quie PG, White GJ, Holmes B, Good RA: In vitro bactericidal capacity of human polymorphonuclear leukocytes: diminished activity in chronic granulomatous disease of childhood. $J$ Clin Invest 46:668-679, 1967

16. Rutenberg WD, Yang MC, Doberstyn EB, Bellanti JA: Multiple leukocyte abnormalities in chronic granulomatous disease: a familial study. Pediatr Res 11:158-163, 1977

17. Bybee JD, Rogers DE: The phagocytic activity of polymorphonuclear leukocytes obtained from patients with the diabetes mellitus. $J$ Lab Clin Med 64:1-13, 1964

18. Mowat AG, Baum J: Chemotaxis of polymorphonuclear leukocytes from patients with diabetes mellitus. $N$ Engl $J$ Med 284:621-627, 1971

19. Gregory JE, Golden A, Haymaker W: Mucormycosis of the central nervous system. A report of three cases. Bull Johns Hopkins Hosp 73:405-419, 1943

20. Brown JR: Human actinomycosis: a study of 181 subjects. Hum Pathol 4 (3): 319-330, 1973

21. Putnam HC, Dockerty MB, Waugh JM: Abdominal actinomycosis: an analysis of 122 cases. Surgery $28(5): 781-800$, 1950

22. King H, Schumacker HB Jr: Splenic studies: susceptibility to infection after splenectomy performed in infancy. Ann Surg 136:239-242, 1952

23. Eraklis AJ, Kevy SV, Diamond LK, Gross RE: Hazard of overwhelming infection after splenectomy in childhood. $N$ Engl J Med 276:1225-1229, 1967

24. Gronvall S, Gammelgaard J, Hanbek A, Holm HA: Drainage of abdominal abscess guided by sonography. $A J R$ $138: 527-529,1982$

25. VanSonnenberg E, Ferruci JF, Mueller PR, Wittenberg J, Simeone JF: Percutaneous drainage of abscesses and fluid collections: technique, results and application. Radiology 142:1-10, 1982

26. Gobien RP, Young JWR, Arry NS, Gobien BS, Valicenti F, Remis HD: CT guidance of percutaneous needle aspiration and drainage of abdominal abscesses. Comput Tomogr $6: 127-133,1982$

27. Aeder MI, Wellman JL, Haaa RR, Han T: Role of surgical and percutaneous drainage in treatment of abdominal abscess. Ann Surg 118:273-280, 1983

28. Halvorsen RA, Korobkin M, Foster WL, Silverman PM, Thompson WM: The variable CT appearance of hepatic abscesses. AJR 141:941-946, 1984

Received: May 15, 1985; accepted: July 24, 1985 